\title{
VIRTUAL INTERNSHIPS: INTERDISCIPLINARY REMOTE WORK FOR UNDERGRADUATES DURING A PANDEMIC
}

\author{
Heidi Dent, Western Carolina University, hdent@email.wcu.edu \\ Barbara Jo White, Western Carolina University, whiteb@email.wcu.edu
}

\begin{abstract}
The benefits of internships have long been touted by accreditation standards for business programs, such as the Association for Advancement of Schools and Colleges of Business (AACSB) and by model curriculum guidelines, such as those for information systems among others. Traditional internships are often individual experiences for students who work on site with companies and a business supervisor serving as a mentor, along with a faculty member who supervises the internship course experience. The traditional internship model does not serve well during a pandemic. This paper describes how traditional internships can be adapted so that undergraduate students can complete their internship by working only remotely with site owner clients and active faculty and internship sponsoring organization participation.
\end{abstract}

Keywords: Internships, Virtual Internship, Remote Work, Interdisciplinary, AACSB

\section{INTRODUCTION}

The coronavirus pandemic forced a massive shift in workers moving from offices to remote work from home environments. After dealing with initial technology issues, such as supplying employees with external monitors or Wi-Fi hotspots as needed (Levy, 2020), productivity has not been adversely impacted. However, while productivity has not drastically declined with the change to working from home, there are opportunities for cost reduction. Employees who work from home, even half the time, are estimated to generate savings of about $\$ 11,000$ a year (Levy, 2020). Even when the economy begins to reopen, workers are not expected to be in a rush to return to office buildings, even after employers have configured office spaces to account for necessary social distancing (Levy, 2020). Employers may not be in a rush to have employees return, preferring to permanently reduce their office footprints and have employees continue working remotely (Clifford, 2020).

How can we prepare business students, particularly information systems students, for a very different world where remote work from home may become the new norm? Working from home on academics alone may not have prepared residential students for future remote work. However, remote internships can do a better job helping students adjust to the new post-pandemic world where they may be working from home consistently.

First, this paper addresses how undergraduate IS curriculum guidelines, as well as, standards for accredited schools of business emphasize engagement via internships and student teams, particularly interdisciplinary teams. Next, various examples from remote internships, specifically those involving technology-related projects, demonstrate similarities and differences from traditional on-site internships. Finally, a project involving an interdisciplinary team of student interns and faculty working remotely and collaboratively to benefit a local for-profit small farm. This project demonstrates how internships can successfully adapt from a face-to-face to a remote-work-only environment. Furthermore, illustrating how undergraduate students can begin preparation for remote work in digital marketing and technology.

\section{LITERATURE REVIEW}

\section{Internships and Business Curriculum}

The Association to Advance Collegiate Schools of Business (AACSB) has long promoted internships for business students as a way of supporting experiential learning. Both the 2013 standards and the 2020 standards support 


\section{Issues in Information Systems}

Volume 21, Issue 3, pp. 11-19, 2020

internships and interdisciplinary projects as experiential learning activities that can benefit students. Internships can also benefit faculty as professional engagement activities (AACSB, 2013). In addition, both sets of standards also support interdisciplinary work by students and faculty (AACSB, 2013 Standards; AACSB, 2020 Standards).

Websites and web-applications that support customer relationship management (CRM) activities are interdisciplinary in nature. Marketing focuses on understanding customer wants and needs and delivering products or services to meet or exceed those needs, while Information Systems focuses on understanding the application's user requirements and designing applications to meet the end-users needs (Albert, Goes \& Gupta, 2004). An interdisciplinary field, digital marketing is more technical in nature and, at many universities, relevant courses may be taught by information systems or marketing, depending on the interests of the faculty (Wymbs, 2011). Curriculum guidelines have been proposed for digital marketing that are based on curriculum models from the Association for Computing Machinery (ACM) and Institute of Electrical and Electronics Engineers (IEEE) because IT is so intertwined with digital marketing (Wymbs, 2011). Technology-centric digital marketing projects lend themselves to interdisciplinary teams of marketing and IS students. Team projects that involve real clients afford students an opportunity to apply classroom learning (Topi, Valacich, Wright, Kaiser, Nunamaker, Jr., Sipior, \& de Vreede, 2009) and team projects have been supported by IS Model curriculum guidelines for over two decades (Davis, Gorgone, Couger, Feinstein, \& Longenecker, Jr., 1997; Gorgone, Davis, Valacich, Topi, Feinstein, \& Longenecker, Jr., 2002; Topi, et al., 2009).

\section{Internship Characteristics}

Traditionally, internships occur on-site at the company's physical location though internships can also be virtual, in which interns do not work on-site at the company's physical location. The term virtual is cause for some confusion , such as its reference in fields like accounting where internships can be part of a game or simulation experience, (Bayerlein, 2015), which can provide students with a simulated work experience. However, the term virtual can also refer to internships that involve students working in a remote fashion (Ruggiero, D., \& Boehm, 2016). Virtual internships, especially in IT and digital marketing, are not new (White, 2002), but are typically used in online, often graduate, programs (Franks \& Oliver, 2012). Virtual internships have been used sparingly for undergraduate programs.

\section{Internship Tasks for Remote Work}

A variety of IT and marketing jobs are well-suited for remote work such as social media (Wortham, 2013) and comprise the majority of the 15 best jobs for remote work (LaPonsie, 2020). One of the 15 best jobs is web development, which often flows from effective brand development strategies, a crucial activity which helps with customer acquisition, retention and building reputation. Case studies illustrating how businesses, particularly small businesses, can build a strong brand found five factors that affect brand identity: vision, aesthetics, play, charisma and trust (Steiner, 2003). Brand building efforts developed for multinational firms can be equally applied to small firms (Bresciani \& Eppler, 2010). Brand-building, from start-ups to strong brands, are vulnerable and can face challenges due to the rise in digital and social media environments that facilitate electronic word-of-mouth (Kozinets, de Valck, Wojnicki, \& Wilner, 2010). Brand is a result of how consumers "feel” about your brand based on their experiences, which are a result of online and offline interactions (Keller, 1998). One of the main sources of "owned media" and consumer online interaction is with a website. An effectively-designed website influences the user experience and ultimately their attitude toward it, which can lead to positive electronic word-of-mouth (Phan \& Pilik, 2018). Aesthetic appeal and usability are key factors in shaping consumer attitudes and behaviors, such as loyalty and satisfaction (Casaló, Flavián, \& Guinalíu, 2008).

Besides web development, user experience (UX) design is another task that lends itself well to working in a remote environment. UX design, listed as a top IT skill for 2020 (Van Nuys, 2019) produces a variety of deliverables including static wireframes, interactive prototypes, site maps and usability/analytics reports (Laubheimer, 2015). Besides UX design, several of the top IT skills for 2020 require skill with analytics (Van Nuys, 2019), and marketing analytics is no different. Marketing analytics utilize tools to quantify and monitor marketing performance and customer information to optimize customer engagement and create a more strategic marketing mix. Effective marketing analytic programs include the people, processes, and technologies to generate insights for performance. Research suggests marketing analytics-oriented firms have a high degree of top management support, a staff member familiar with marketing analytics and proper funding provide key performance drivers to assist in marketing analytics processes (Branda, Lala, \& Gopalakrishna, 2018). Developing a framework for a low-resource firm offers opportunities to 
reduce barriers for marketing analytic orientation (MAO). Many low-resource firms either outsource (remote) digital marketing or participate in the bare minimum. Digital marketing encompasses search engine optimization (SEO), search engine marketing (SEM), content marketing, website development and analytics management. Oftentimes these positions in industry are offered with the option to work remotely, therefore, preparing students through remote internships will help to better prepare them for remote work in the future.

The next section describes how a typical full-time internship, created for a single student working with one business with on-site work was adapted in response to the recent pandemic to two students working for the farm remotely.

\section{ADAPTING FROM TRADITIONAL TO INTERDISCIPLINARY TEAM-BASED REMOTE WORK INTERNSHIPS WITH ACTIVE FACULTY PARTICIPATION}

The internship for the solar-powered family farm was funded by EmPOWERing Mountain Food Systems (EMFS) Food and Farm Apprenticeship Program, a three-year project grant funded through the Appalachian Regional Commission (ARC) POWER Initiative designed to assist farm and local food-based businesses in the seven far western counties and the Eastern Band of Cherokee Indians of North Carolina. The EMFS project is itself hosted through North Carolina State University and the Center for Environmental Farming Systems (CEFS), in partnership with North Carolina State University Cooperative Extension Services and the Cherokee Preservation Fund. The EMFS Food and Farm Apprenticeship Program is one of ten program objectives to create a beneficial economic impact in the region for farms and local food-based businesses.

The farm offers classes (farm to table cooking; gardening, and food preservation, etc.), metalsmithing products (tools, garden structures, housewares, art, furniture, and custom work and repairs, etc.), and farm-stays. The farm is looking for information systems and marketing assistance focused on advertising strategies and using technologies (website and social media) effectively to build a stronger digital presence in order to build brand awareness and increase sales.

To convert the face-to-face internships to remote-work internships meant adapting the job description, communication tools, and student, site owner client, and faculty participation (see Table 1 on the following page for an overview of tasks and tools connected to this project).

\section{Adapting the Internship Job Description}

While the original internship job description, which outlined website design and social media tasks well-suited for remote work environment, other parts of the job description (see Figure 1 below) had to be modified given the stayat-home order associated with the pandemic.

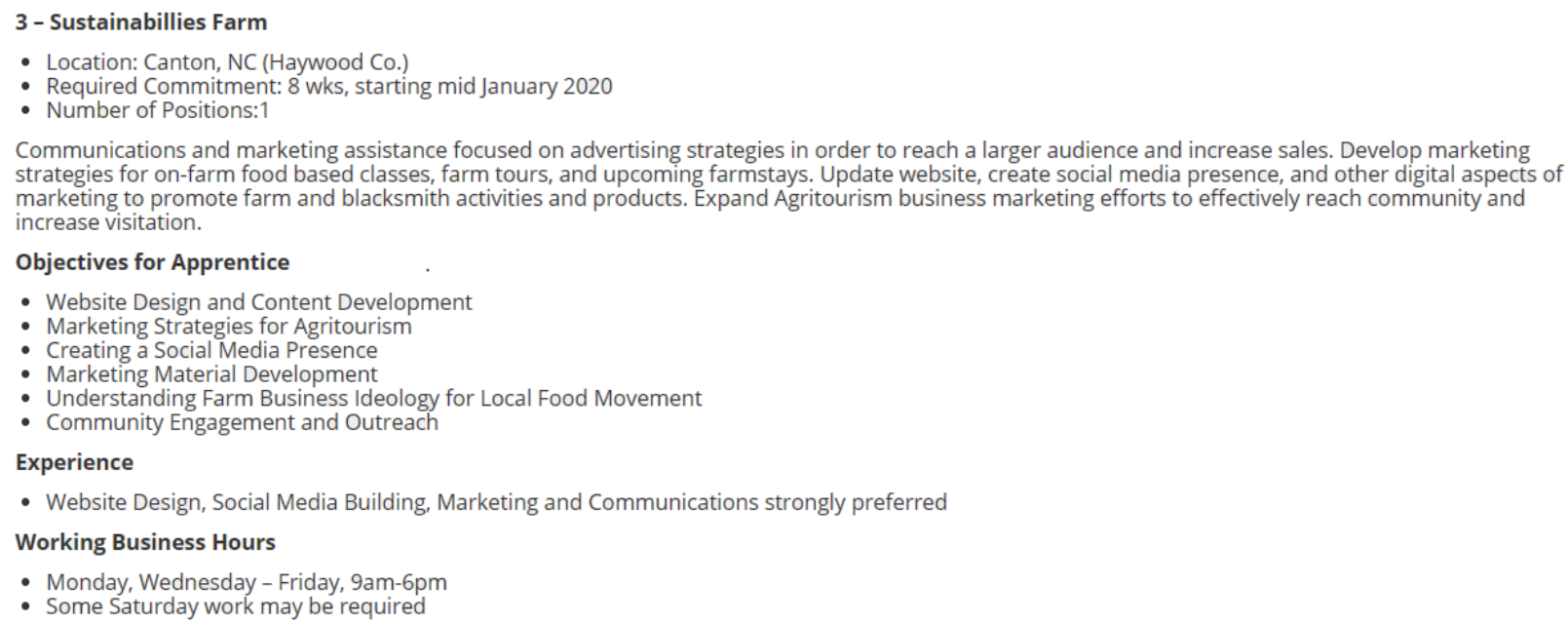

Figure 1. Original Job Description Posted by EmPOWERing Mountain Food Systems 
Specifically, the working hours and the requirement for some Saturday work at local farmers' markets had to be dropped and replaced with an all-remote-work requirement and the start date was moved to mid-May.

\section{1: Sustainabillies (Haywood Co.) \\ Canton, NC}

The apprentice will focus on communications and marketing assistance; focused on advertising strategies in order to reach a larger audience and increase sales. Tasks include developing marketing strategies for future on-farm food-based classes, farm tours, and upcoming farm stays. An important role will be to update the website, create social media presence, and other digital aspects of marketing to promote farm and blacksmith activities and products. Additionally, the apprentice will assist in the expansion of Agritourism business marketing efforts to effectively reach the community and increase visitation.

\section{Learning Objectives}

- Website design and content development.

- Marketing strategies for Agritourism.

- Creating a Social Media presence.

- Marketing material development.

- Understanding farm business ideology for the local food movement.

- Community engagement and outreach.

\section{Experience}

- Website design and development using user-friendly website builders with mobile compatible sites with no coding required.

- Social media platforms (Facebook and Instagram).

- Internet-based graphic design platform (Canva).

- Marketing and communication skills are strongly preferred.

\section{Working Business Hours}

Monday, Wednesday - Friday 9 am - 6 pm

Some Saturday work may be required

\section{Apprenticeship Duration}

Anticipated Start Date: May 15-23

( 8 weeks) for $20 \mathrm{hrs}$ a week

(Remote working environment)

Figure 2. Adapted Job Description Posted by EmPOWERing Mountain Food Systems

Besides the remote work environment, the internship was moved was split into two positions. The original 160-hour apprenticeship was split into two 80-hour internship positions in order to allow for collaboration between students

\section{Adapting Site Owner Client Participation}

In order to facilitate a remote pandemic-compliant apprenticeship, the content creation transitioned to require more commitment from the site owner client (see Table 1 on the following page). In a typical digital marketing business arrangement, the site owner client often attempts to defer to the vendor initially regarding content creation, with the vendor having to consistently encourage the site owner client to more actively participate. However, the same is not true for work adapted to a remote-only work environment. 


\section{Issues in Information Systems \\ Volume 21, Issue 3, pp. 11-19, 2020}

In cases, such as the pandemic, where there is no physical contact between providers and site owner clients, the active participation of the site owner client is heightened and apparent to all. In this type of remote-only work environment, the agency-client relationship and content co-creation, where the site owner client works with faculty or students to create content, is very much an integral part of a successful outcome.

Table 1. Virtual Internship IS Tools for Digital Marketing and Website: Involvement Overview

\begin{tabular}{|c|c|c|c|c|c|c|}
\hline $\begin{array}{l}\text { Information } \\
\text { Virtual Inte }\end{array}$ & $\begin{array}{l}\text { tem Tools For Digital Marketing and Website } \\
\text { p: Involvement Overview }\end{array}$ & 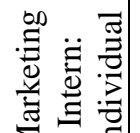 & 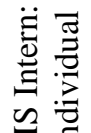 & 营氖总 & : & 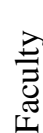 \\
\hline $\begin{array}{l}\text { UX } \\
\text { Wireframe }\end{array}$ & Task 1: Basalmiq: Outline & - & - & - & - & - \\
\hline & Task 1: Install WordPress & & & & & - \\
\hline & Task 2: Setup Staging Environment & & - & - & & $\bullet$ \\
\hline WordPress & Task 3: Migrate Website & & & & & $\bullet$ \\
\hline & Task 4: Testing & & & - & - & $\bullet$ \\
\hline & Task 5: Create Training Guide & & & $\bullet$ & & $\bullet$ \\
\hline & Task 1: Create store & & - & - & - & \\
\hline Shonif & Task 2: Upload Products & & & $\bullet$ & $\bullet$ & $\bullet$ \\
\hline shopity & Task 3: Integrate with Website & & & $\bullet$ & & $\bullet$ \\
\hline & Task 4: Create Training Guide & & & - & $\bullet$ & $\bullet$ \\
\hline ת & Task 1: Social Graphics & & & - & - & $\bullet$ \\
\hline Calivd & Task 2: Marketing Collateral & $\bullet$ & & & - & $\bullet$ \\
\hline Google & Task 1: Connect to website & & $\bullet$ & & & $\bullet$ \\
\hline Analytics & Task 2: Measurement/Traction & & - & & & $\bullet$ \\
\hline & Task 1: Create Channel & - & & & & \\
\hline & Task 2: Channel Manager & $\bullet$ & & & $\bullet$ & \\
\hline YouTube & Task 3: Content Creation & & & & $\bullet$ & $\bullet$ \\
\hline & Task 4: Analytics & & - & & & $\bullet$ \\
\hline & Task 5: Integrate with Website & & & - & & $\bullet$ \\
\hline & Task 1: Page Manager & $\bullet$ & & & & \\
\hline & Task 2: Content Creation & $\bullet$ & & & $\bullet$ & • \\
\hline Facebook & Task 3: Messenger Chatbot & $\bullet$ & & & & $\bullet$ \\
\hline & Task 4: Analytics & & - & & & $\bullet$ \\
\hline & Task 5: Integrate with Website & & & - & & $\bullet$ \\
\hline & Task 1: Page Manager & $\bullet$ & & - & - & - \\
\hline Incta 0 ram & Task 2: Content Creation & & & - & $\bullet$ & \\
\hline Instagram & Task 3: Analytics & $\bullet$ & & & & $\bullet$ \\
\hline & Task 4: Integrate with Website & & & - & & \\
\hline & Task 1: Content Collection & & & - & & - \\
\hline Teams & Task 2: Discussion/Collaboration & & & - & - & - \\
\hline & Task 3: Project Management & & & $\bullet$ & & $\bullet$ \\
\hline & Task 1: Hosting & & & & - & - \\
\hline GoDaddy & Task 2: Security & & & & & - \\
\hline & Task 3: Backup/Monitoring & & & & $\bullet$ & $\bullet$ \\
\hline Social Text & Task 1: ForSocial: Tool \& Output Research & & - & & & - \\
\hline Analysis & Task 2: RapidMinder & & & - & & \\
\hline & Task 1: Hashtag IO: Tool \& Output Research & & & - & & - \\
\hline Research & Task 2: Keywords.io & & & - & & • \\
\hline & Task 3: Tool \& Output Research & & & - & & - \\
\hline $700 m$ & Task 1: Weekly Collaboration Team Meeting & & & - & - & - \\
\hline 2000 & Task 2: Weekly Collaboration Client & & & - & - & - \\
\hline
\end{tabular}




\section{Adapting Faculty Participation}

In typical internships that count as college courses, faculty members play a central role where tasks contributing to course grades and credit are concerned. Tasks often included in internships that count as courses include journals and reflections, submitted periodically throughout the semester. However, students can participate in internships without them counting as course credit. In these instances, faculty play a much lesser role, which may be limited to congratulatory messages and conversation if the student converses with faculty members about their internship experiences. While encouraged by the AACSB to participate in internships (AACSB, 2013 Standards; AACSB, 2020 Standards), faculty participation often "counts" as professional engagement activity or, if there are provisions for it, as a scholarship of engagement/scholarship of application artifact (White, Cruz, Ellern, Ford, \& Moss, 2012). No matter how professional engagement activities "count” for faculty, rarely do faculty actively participate with students in an internship experience.

\section{Adapting Student Participation}

Undergraduate students may not have fully developed their abilities to work independently and compared to older workers (Raghuram, Garud, Wiesenfeld, \& Gupta, 2001), which may negatively affect student performance on internship tasks. One solution to more positively affect student work is to have students work in teams, which can raise the level of job performance if team size is not so large that students can shirk their responsibilities. There are a variety of methods used for the process of team selection (Taylor \& White, 2011). While students often have input in team selection in projects used in information systems courses and it is rarer that clients have input in student team selection, (Vartianinen, 2005) the same cannot be said for the real world where students don't have input as to who they work with. In fact, like random assignment on class projects (Vaughn, 2001), internship selection can mirror a real-world workplace environment in which students need to find ways to work with whomever is on their work teams. When students aren't familiar with each other on work teams, a barrier to trust formation can arise with fellow team members (Vartianinen, 2005), which may be exacerbated by student teams in which students come from different disciplines. Though interdisciplinary work projects again mirror the real world well (Ducoffe, Tromley \& Tucker, 2006) and are supported by the AACSB (AACSB, 2013 Standards; AACSB, 2020 Standards), students often do not get the opportunity to work with students from other disciplines, though there are exceptions (Willey \& White, 2019). Work was adapted so that students could work on their own, to increase ownership and work as a student team. In addition, students were set to complete some work with the site owner client or with faculty (see Table 1 on the previous page).

\section{Adapting Communication and Other Tools}

Keeping projects on schedule requires contact between student teams and instructors (Helwig, 2006), which is especially critical when faculty instructors are active participants. Student teams similarly need to stay in close contact with site owner clients. Weekly, typically hour-long meetings were scheduled for major stakeholders including students, the site owner client, faculty and the director of the internship sponsoring organization.

Adapting the weekly meetings in a remote setting was no different than what is happening in the real world of remote work during the pandemic and required the use of video-conferencing and document sharing tools. While the use of communication tools may be of secondary importance in face-to-face settings, these same video conferencing and document sharing tools were of primary importance for online-only work

\section{STAKEHOLDER REACTION TO REMOTE WORK INTERNSHIP}

Weekly meetings with stakeholders (students, faculty, site owner client, and sponsoring organization representative) have been held using Zoom. These meetings typically last one hour and involve faculty and student apprentices discussing deliverables for the week along with screen-sharing where necessary of software tools used along with a website walk-through.

From these meetings, reaction to student participation from the site owner client and from the internship sponsoring organization has been positive. The site owner client taught biology at a community college and is very familiar with working with students, giving them positive feedback, and encouraging them to speak up if they seem nervous, which 


\section{Issues in Information Systems}

Volume 21, Issue 3, pp. 11-19, 2020

they did at the beginning. The internship sponsoring organization also has commended students for their work thus far on the project during the weekly video conference meetings. The meetings also cover critiques of the website and changes to be made. In addition to being positive about student work, the site owner client and internship sponsoring organization has been very positive about faculty participation as well.

\section{CONCLUSIONS}

When the pandemic created a situation where the farm apprenticeship program was in jeopardy because the engagement piece between interns and site owner clients was not possible, the director relied on faculty to assure that good work could be done completely remotely by students. An important factor in the relationship cycle is trust, honesty and commitment. Site owner clients naturally value these factors during the "working phase" of the lifecycle (Fam \& Waller, 2008). When faculty were involved as active participants and part of the client-agency relationship, the internship sponsoring organization was even more comfortable with the idea of students working in a remote-only environment.

It is difficult to know how global pandemics will affect internships and jobs our graduates in information systems and marketing hope attain in the future. However, with employees used to working productively from home and with employers benefitting from cost savings associated with remote work, it could be likely that remote work is here to stay. In that case, it is incumbent on colleges and universities to better prepare our graduates for a changed work world.

\section{ACKNOWLEDGEMENTS}

The authors would like to thank Christina Newhouse, who is the EMFS Food and Farm Apprenticeship Program Manager. Ever an innovator, Christina was able to move seven apprenticeship positions to completely remote work so that collectively with area students and WCU College of Business faculty, we could work together to assist forprofit small farms in the Western North Carolina region with their rebranding, digital marketing, social media and website development needs as they work to survive the pandemic.

\section{REFERENCES}

AACSB International (n.d.) 2013 Standards for Business Accreditation. Available: https://www.aacsb.edu//media/aacsb/docs/accreditation/business/standards-and-tables/2018-business standards.ashx?la=en\&hash=B9AF18F3FA0DF19B352B605CBCE17959E32445D9

AACSB International (n.d.). 2020 Standards for Business Accreditation. Available: https://www.aacsb.edu//media/aacsb/docs/accreditation/business/standards-andtables/proposed\%202020\%20aacsb\%20business\%20accreditation\%20standards\%20\%20final\%20draft\%20\%20april\%206\%202020.ashx?la=en\&hash=B40646D6F0057FBAF289B3B04888A 33BB2741A3D

Albert, T. C., Goes, P. B., \& Gupta, A. (2004). Gist: A Model for Design and Management of Content and Interactivity of Customer-Centric Web Sites. MIS Quarterly, 28(2), 161-182. https://doiorg.proxy195.nclive.org/10.2307/25148632

Bayerlein, L. (2015). Curriculum innovation in undergraduate accounting degree programs through "virtual internships”. Education+ Training, 57(6), 673-684.

Berger, J., Humphreys, A., Ludwig, S., Moe, W.W., Netzer, O., \& Schweidel, D. (2020). Uniting the Tribes: Using Text for Marketing Insight. American Marketing Association, 84(1),1-25.

Branda, A.F., Lala, V., \& Gopalakrishna, P. (2018). The marketing analytics orientation (MAO) of firms: identifying factors that create highly analytical marketing practices. Journal of Marketing Anal (6) 8494. 
Brescani, S., \& Eppler, M.J. (2010). Brand new ventures? Insights on start-ups' branding practices. Journal of Product \& Brand Management, 19(5), 356-366.

Casaló, L. V., Flavián, C., \& Guinalíu, M. (2008). The role of satisfaction and website usability in developing customer loyalty and positive word-of-mouth in the e-banking services. International Journal of Bank Marketing, 26(6), 399-417.

Clifford, L. (May 11, 2020). Working from home during coronavirus is going so well that this Fortune 100 company is going to keep doing it--permanently. Accessed May 11--Available at:

https://fortune.com/2020/05/11/permanent-work-from-home-coronavirus-nationwide-fortune-100/ fix this ref

Davis, G. B., Gorgone, J. T., Couger, J. D., Feinstein, D. L., \& Longenecker, Jr., H. E. (1997). "IS ‘97 Model Curriculum and Guidelines for Undergraduate Degree Programs in Information Systems,” ACM, New York, NY and AITP [formerly DPMA), Park Ridge, IL.

Ducoffe, S.J., Tromley, C.L., \& Tucker, M. (2006). Interdisciplinary, team-taught, undergraduate business courses: The impact of integration. Journal of Management Education, 30(2), 276-294.

Fam, K.-S., \& Waller, D. (2008). Agency-Client Relationship Factors Across Life-Cycle Stages. Journal of Relationship Marketing, 7(2), 217-236. https://doi-org.proxy195.nclive.org/10.1080/15332660802279503

Franks, P. C., \& Oliver, G. C. (2012). Experiential learning and international collaboration opportunities: virtual internships. Library Review 61(4), 272-285.

Gorgone, J. T., Davis, G. B., Valacich, J. S., Topi, H., Feinstein, D. L., \& Longenecker, Jr., H. E. (2002). “IS 2002 Model Curriculum and Guidelines for Undergraduate Degree Programs in Information Systems," ACM, New York, NY and AITP (formerly DPMA), Park Ridge, IL.

Helwig, J. (2006). Experiential learning and international collaboration opportunities: virtual internships. Information Systems Education Journal 4(62), 1-8.

Keller, K.L. (1998), Strategic Brand Management, Prentice Hall, Upper Saddle River, NJ.

Kozinets, R.V., de Valck, K., Wojnicki, A.C., \& Wilner, S.J.S. (2010). Networked narratives: Understanding word-of-mouth marketing in online communities. Journal of Marketing, 74, 71-89.

LaPonsie, M., (April 13, 2020) 15 best jobs for remote work. Available: https://money.usnews.com/careers/bestjobs/slideshows/best-remote-working-jobs

Laubheimer, P. (2015, October 18). Which UX deliverables are most commonly created and shared? Retrieved from https://www.nngroup.com/articles/common-ux-deliverables/

Levy, A. (May 11, 2020). Working from home is here to stay, even when the economy reopens. Available at: https://www.cnbc.com/2020/05/11/work-from-home-is-here-to-stay-after-coronavirus.html

Phan, Q. P. T., \& Pilik, M. (2018). The Relationship between Website Design and Positive E-WOM Intention: Testing Mediator and Moderator Effect. Journal of Business Economics \& Management, 19(2), 382398.

Raghuram, S., Garud, R., Wiesenfeld, B., \& Gupta, V. (2001). Factors contributing to virtual work adjustment. Journal of Management, 27(3), 383-405.

Ruggiero, D., \& Boehm, J. (2016). Design and development of a learning design virtual internship program. International Review of Research in Open and Distributed Learning, 17(4), 105-120. 
Steiner, L. (2003). "Roots of identity in real estate industry”, Corporate Reputation Review, 6(2), 178-196.

Taylor, M., \& White, B. J. (2011). Real world information systems projects in the classroom: Factors to consider. Issues in Information Systems, 12(2), 135-141.

Topi, H., Valacich, J. S., Wright, R. T., Kaiser, K., Nunamaker, Jr., J. F., Sipior, J. C., \& de Vreede, G. J. (2009). IS 2010: Curriculum Guidelines for Undergraduate Degree Programs in Information Systems. Communications of the Association for Information Systems, 26, 359-428.

Vartianinen, T. (2005). Moral Conflicts in a Project Course in Information Systems Education. Jyväskylä: Department of Computer Science and Information Systems, University of Jyväskylä.

Vaughn, Jr., R. B. (2001). Teaching industrial practices in an undergraduate software engineering course. Computer Science Education, 11(1), 21-32.

Van Nuys, A., (Dec. 28, 2019) New LinkedIn research: Upskill your employees with the skills companies need most in 2020. Available: https://learning.linkedin.com/blog/learning-thought-leadership/most-indemand-skills-2020

White, G. W. (2002). University Business Internships: The Corporate Advantage. International Business \& Economics Research Journal (IBER), 1(1), 105-108.

White, B. J., Cruz, L., Ellern, J., Ford, G., \& Moss, H. (2012). Bound by Tradition? Peer Review and New Scholarship: An Institutional Case Study. Research in Higher Education Journal, 1-18.

Willey, L., \& White, B. J. (2019). Emphasizing security and writing in a cross-disciplinary course for computer information systems and business law students. Issues in Information Systems, 20(2), 38-46.

Wortham, J. (2013, February 02). Virtually There: Working Remotely. Retrieved May 13, 2020, 2017, from http://www.nytimes.com/2013/02/03/education/edlife/virtual-internships.html?mcubz=0

Wymbs, C. (2011). Digital Marketing: The Time for a New “Academic Major” Has Arrived. Journal of Marketing Education, 33(1), 93-106. 